\title{
Factors Related to Gastritis Events At The Ages 17-21 Years Old in The Work Area of Pesanggrahan Public Health Center (Puskesmas) in 2018
}

\author{
Ida Setyaningsih \\ Master of Public Health Study Program, Faculty of Public Health, Muhammadiyah University of \\ Jakarta \\ Email: idasetyan@gmail.com
}

\begin{abstract}
Gastritis that occurs in developing countries is mostly experienced by young people with a predominant age of 20 years. The recurrence experienced can increase the risk of developing a disease that is more dangerous and difficult to cure, even causing death. This study was to determine the factors associated with the incidence of gastritis at the age of 17-21 years in the work area of the Pesanggrahan Public Health Center in 2018. This study uses a quantitative type of research with a Case-Control study design. The population in this study were patients aged 17-21 years at the Pesanggrahan Public Health Center for the period June-August 2018. Cases were patients diagnosed with gastritis and controls were non-gastritis patients. Cases and controls were selected by accidental sampling technique as many as 50 people with a ratio of 1:1. Data were collected through interviews and analysis using the Chi-Square test with a value of $=0.05$. The study showed that there was a relationship between several risk factors and the incidence of gastritis, including gender $(O R=2,986$, $95 \% C I=2,680-3,654)$, knowledge (OR=2,528, 95\% CI=1,112-5,744), eating frequency $(O R=9,333$, 95\% CI =1,121-77,704), Meal Time Interval $(O R=5,670,95 \% C I=2,144-14,997)$, Frequency of Drinking Tea $(O R=2,923,95 \% C I=1,245-6.865)$, Frequency of Spicy $(O R=3.407,95 \% C I=1.401$ 8.285), Frequency of Acid Eating $(O R=1.196,95 \% C I=1.801-2.478)$, Frequency of Instant Noodles $(O R=10.444,95 \% C I=2.855-38.211)$ while the risk factors which are not related to the incidence of gastritis are education, frequency of drinking coffee, frequency of drinking soda. It is necessary to improve health programs such as education, health promotion targeting teenagers in schools.
\end{abstract}

Keywords: Gastritis, Risk Factor 


\section{INTRODUCTION}

The ongoing health development in Indonesia is currently faced with two problems, one of which is infectious diseases which are still a public health problem that has not been addressed, on the other hand, there has been an increase in cases of non-communicable diseases (NCDs) which are mostly caused by lifestyle due to urbanization, globalization, and modernization (Ministry of Health, 2013).

Nowadays, with the modern era, more and more diseases arise due to the human lifestyle (Cahyono, 2008). One of the health problems faced today is gastrointestinal diseases such as gastritis. People, in general, know gastritis as ulcer disease, which is a disease that is not seen as a big problem. If this condition is not resolved quickly, it can cause bleeding (hemorrhagic gastritis) so that a lot of blood comes out and collects in the stomach, besides that it can cause gastric ulcers or gastric cancer which can cause death (Rizema, 2013).

Based on research by the World Health Organization (WHO) with several countries in the world, data on the number of gastritis sufferers in Canada is $35 \%$, China is $31 \%$, France is $29.5 \%$, England is $22 \%$, Japan is $14.5 \%$. In the world, the incidence of gastritis is around 1.8-2.1 million of the total population every year. The incidence of gastritis in Southeast Asia is around 583,635 of the total population each year (WHO, 2011). In Indonesia, cases of gastritis have a fairly high prevalence, namely 274,396 cases out of $238,452,952$ people. From research and observations conducted by the Indonesian Ministry of Health, the incidence of gastritis in several cities in Indonesia with the highest number reaching 91.6\%, namely in the city of Medan, then in several cities others such as Jakarta 50\%, Denpasar 46\%, Palembang 35.3\%, Bandung 32.5\%, Aceh 31.7\%, Surabaya 31.2\%, Pontianak $31.2 \%$. This is caused by an unhealthy diet (Gustin, 2011).

Gastritis that occurs in developing countries is mostly experienced by young people with an age dominated by 20 years of $78.6 \%$ and with gastritis cases generally occurring in people aged 60 years, $57.8 \%$ of patients with gastritis and gastritis aged 40 years $77,8 \%$ are caused by internal factors, namely conditions that trigger excessive gastric acid secretion and external factors that cause irritation and infection (Selviana, 2015). According to research conducted by Anggita (2012), gastritis suffered from a young age can relapse which increases the risk of developing a disease that is more dangerous and difficult to cure, even causing death.

According to research (Fahrizal, 2009) from 17 villages in the Puskesmas Tambang District Work Area, the mining village is the highest village with the number of gastritis sufferers at the adolescent age level (15-19 years), namely 30 people out of 122 sufferers. Then based on research conducted on adolescents aged 14-17 years old girls suffer from gastritis more than boys with a percentage of $27 \%$ girls and $16 \%$ men (Annisa, 2009). 
If left untreated, this gastritis will get worse, especially if there is no proper and correct dietary arrangement, it will cause a recurrence effect which will interfere with the patient's activities (Sulastri, 2012) This is supported by Surya and Marshall's research from 2007 to 2008 saying that if this gastritis is not handled properly it will cause complications that lead to severity, namely gastric cancer and peptic ulcer. In addition, other complications that can occur in acute gastritis include gastrointestinal bleeding and if there is enough bleeding it will cause anemia which can result in death.

Based on data obtained from the Pesanggrahan Health Center regarding the incidence of gastritis in 2017 from January to December there were a total of 291 cases with the highest increase in gastritis in May of 69 cases, 67 cases in March, and 28 cases in June. There were also cases in 2018 from January to April with a total of 115 cases with gastritis cases being 76 cases in February, April 18 cases, March 11 cases, and January 10 cases.

This study aims to determine the factors associated with the incidence of gastritis in the work area of the Pesanggrahan Health Center in 2018.

\section{METHODS}

This research is a type of quantitative research using an analytical study design with a CaseControl study approach. The population in this study were patients aged 17-21 years who were recorded in the Work Area of the Pesanggrahan Health Center. Cases are adolescents aged 17-21 years diagnosed with gastritis by health personnel and recorded in the medical record at the Pesanggrahan Health Center in the period June-August 2018. Controls are adolescents aged 17-21 years who were not diagnosed by health personnel and recorded in the medical record. at the Pesanggrahan Health Center in the period June-August 2018. The number of samples used was 100 respondents, which were divided into 50 respondents in the case group and 50 respondents in the control group. Collecting data using questionnaires and FFQ tables by interviewing respondents with questionnaires, then doing univariate and bivariate analysis.

\section{RESULT AND DISCUSSION}

Table 1 illustrates that there are 34 people aged $>20$ years, the education level of SMP and SMA / SMK is the same as many as 25 people. It can also be seen that there is a low level of knowledge as many as 26 people, the frequency of irregular eating is 49 people and the interval of eating time $>6$ hours is 43 people. 
Table 1. Distribution of Education, Gender, Knowledge, Frequency of Eating, Time to Eat

\begin{tabular}{lcc}
\hline \multicolumn{1}{c}{ Variabel } & Gastritis & No Gastritis \\
\hline Education & 25 & 31 \\
SMP & 25 & 19 \\
SMA/SMK & 36 & 31 \\
\hline Gender & 14 & 19 \\
Female & & \\
Male & 26 & 15 \\
\hline Knowledge & 24 & 35 \\
Low & & \\
High & 49 & 42 \\
\hline Eat Frequency & 1 & 8 \\
Not a Routine & & \\
Routine & 43 & 26 \\
\hline Break meal time & 7 & 24 \\
$>6$ hours & & \\
$\leq 6$ hours & & \\
\hline
\end{tabular}

The bivariate test results illustrate that there is a relationship between age and the incidence of gastritis. Adolescents who are> 20 years old have a 4.9 times greater risk of developing gastritis. On the gender variable, the results of statistical tests showed that there was a relationship between sex and the incidence of gastritis in adolescents as indicated by $p=0.004(p<0.05)$. Based on these statistical results, the female gender has a 2.9 times greater chance of suffering from gastritis. In the knowledge variable, the results of statistical tests showed that there was a relationship between knowledge and the incidence of gastritis in adolescents as indicated by $\mathrm{p}=0.042$, low knowledge on adolescents had a 1.1 times risk of suffering from gastritis. the frequency of eating with the incidence of gastritis in adolescents is $\mathrm{p}=0.031$. Adolescents who have irregular eating frequency have a 9.3 times risk of developing gastritis. In the variable frequency of drinking tea, statistical test results show that there is a relationship between the frequency of drinking tea with the incidence of gastritis in adolescents indicated by $\mathrm{p}=0.022(\mathrm{p}<0.05)$. Based on these statistical results, the frequency of drinking tea has a 2.9 times greater chance of suffering from gastritis. In addition, some data shows a relationship, namely the variable frequency of spicy eating with the incidence of gastritis shown by statistical results, namely $\mathrm{p}=0.011$, adolescents have a 3.4 times risk of suffering from gastritis when consuming excessive spicy food, then there is also a relationship between the frequency of eating sour and the incidence of gastritis. gastritis of 0.001 , it can be interpreted that adolescents who consume acidic foods have a 1.1 times risk of suffering from gastritis, besides the frequency of consuming instant noodles can also affect the incidence of gastritis with a statistical test of 0.003 , adolescents who consume instant noodles have a 10.4 times risk of suffering from gastritis. 
Table 2 . Bivariate Analysis of Gastritis Factors in Adolescents

\begin{tabular}{|c|c|c|c|c|c|c|}
\hline \multirow{2}{*}{ No. } & \multirow{2}{*}{ Variable } & \multirow{2}{*}{ Category } & \multicolumn{2}{|c|}{ Gastritis Status } & \multirow{2}{*}{ Nilai p } & \multirow{2}{*}{ OR $(95 \%$ CI $)$} \\
\hline & & & Gastritis & No Gastritis & & \\
\hline \multirow{2}{*}{1.} & Gender & Female & $36(72,0 \%)$ & $31(62,0 \%)$ & \multirow{2}{*}{0,004} & 2,986 \\
\hline & & Male & $14(28,0 \%)$ & $19(38,0 \%)$ & & $(2,680-3,654)$ \\
\hline \multirow{2}{*}{2.} & Knowledge & Low & $26(52,0 \%)$ & $15(30,0 \%)$ & \multirow{2}{*}{0,042} & 2,528 \\
\hline & & High & $24(48,0 \%)$ & $35(70,0 \%)$ & & $(1,112-5,744)$ \\
\hline \multirow{2}{*}{3.} & Eating & Irregular & $49(98,0 \%)$ & $42(84,0 \%)$ & \multirow{2}{*}{0,031} & 9,333 \\
\hline & frequency & Reguler & $1(2,0 \%)$ & $8(16,0 \%)$ & & $(1,121-77,704)$ \\
\hline \multirow{2}{*}{4.} & Break meal time & $>6$ Hours & $43(86,0 \%)$ & $26(52,0 \%)$ & \multirow{2}{*}{0,001} & 5,670 \\
\hline & & $\leq 6$ Hours & $7(14,0 \%)$ & $24(48,0 \%)$ & & $(2,144-14,997)$ \\
\hline \multirow{2}{*}{5.} & Tea drinking & $\geq 4$ Cup/day & $38(76,0 \%)$ & $26(52,0 \%)$ & \multirow{2}{*}{0,022} & 2,923 \\
\hline & frequency & $<4$ Cup/day & $12(24,0 \%)$ & $24(48,0 \%)$ & & $(1,245-6,865)$ \\
\hline \multirow{2}{*}{6.} & Coffee drinking & $\geq 3$ Cup/day & $25(50,0 \%)$ & $24(48,0 \%)$ & \multirow{2}{*}{0,967} & 1,068 \\
\hline & frequency & $<3$ Cup/day & $25(50,0 \%)$ & $26(52,0 \%)$ & & $(0,554-2,060)$ \\
\hline \multirow{2}{*}{7.} & Frequency of & $\geq 3$ Bottles/week & $20(40,0 \%)$ & $25(50,0 \%)$ & \multirow{2}{*}{0,421} & 0,667 \\
\hline & drinking soda & $<3$ Bottles/week & $30(60,0 \%)$ & $25(50,0 \%)$ & & $(0,302-1,472)$ \\
\hline \multirow{3}{*}{8.} & Frequency of & $\geq 3$ & $40(80,0 \%)$ & $27(54.0 \%)$ & \multirow{3}{*}{0,011} & 3,407 \\
\hline & eating spicy & teaspoon/meal/day & $10(20,0 \%)$ & $23(46.0 \%)$ & & $(1,401-8,285)$ \\
\hline & & $<3$ teaspoon/meal/day & & & & \\
\hline \multirow{3}{*}{9.} & Frequency of & $\geq 3$ & $22(44.0 \%)$ & $40(80.0 \%)$ & \multirow{3}{*}{0,001} & \multirow{3}{*}{$\begin{array}{l}1,196 \\
(1,801-2,478)\end{array}$} \\
\hline & eating acid & teaspoon/meal/day & $28(56,0 \%)$ & $10(20,0 \%)$ & & \\
\hline & & $<3$ teaspoon/meal/day & & & & \\
\hline \multirow{2}{*}{10.} & Frequency of & $\geq 4 \mathrm{x} /$ month & $47(94,0 \%)$ & $30(60,0 \%)$ & \multirow[b]{2}{*}{0,003} & \multirow{2}{*}{$\begin{array}{l}10,444 \\
(2,855-38,211)\end{array}$} \\
\hline & $\begin{array}{l}\text { consumption of } \\
\text { instant noodles }\end{array}$ & $<4 \mathrm{x}$ month & $3(6,0 \%)$ & $20(40,0 \%)$ & & \\
\hline
\end{tabular}

Research shows that there is a relationship between age and the incidence of gastritis in the work area of the Pesanggrahan Public Health Center. The results of this study are reinforced by research conducted by Rahmi (2010), the most common age of gastritis sufferers is between 20-33 years. This age is an age with various activities due to work and other activities. This is in line with research conducted by Andi (2014) that the most common age for gastritis sufferers is between 15-24 years and is dominated by women. So they are more likely to be exposed to factors that increase the risk of developing gastritis, related to irregular eating patterns and stress at work, and unhealthy lifestyles (Gustin, 2011). In this study, it was also seen that the female gender had a 2.9 times greater risk of suffering from gastritis than male respondents.

The results of this study are supported by research by Apriadji (2013) that gender is an internal factor that determines nutritional needs, so there is a relationship between gender and the occurrence of gastritis. Gender determines the size of a person's nutritional needs. Individual growth and development are very different between men and women (Sumarni, 2017). ). This is by what Andi (2014) stated that people with gastritis are more likely to suffer from women aged 15-24 years because women pay more attention to their body image so that many of them delay and even reduce the portion of food according to their needs so that they have the right body portion. perfect. Other results from this study also 
showed that low knowledge had a 2.5 times greater risk of suffering from gastritis than respondents with high knowledge. This is by research conducted by Su (2008) which states that increasing knowledge will reduce the risk of developing gastric disorders. According to research conducted by Maya (2016), it was found that the average value of respondents regarding knowledge before being given health counseling and after being given counseling increased from $23.3 \%$ to $100 \%$ with a p-value $=0.000$ and there was an increase in the number of respondents who had positive attitudes. positive between before and after health education that is $40.0 \%$ to $86.7 \%$ with p-value $=0.001$. So it can be concluded that there is an influence on the level of knowledge among adolescents about efforts to prevent gastritis and the attitudes of adolescents to prevent gastritis.

The results showed that there was a relationship between the frequency of eating and the incidence of gastritis in the working area of the Pesanggrahan Community Health Center. Based on the results of the Chi-square test, the p-value is 0.031 because the p-value is $<(0.05)$ so that Ho is rejected. The odds ratio $(\mathrm{OR})=9,333(\mathrm{OR}>1)$ with $95 \% \mathrm{CI}=1,121-77,704$ shows that respondents who have a frequency of eating irregularly have a 9.3 times greater risk of suffering from gastritis than respondents who eat regularly. According to research conducted by Yunita (2010), the incidence of gastritis is influenced by the regularity and frequency of eating. Another study conducted by Rahmawati (2010) states that eating attitudes and actions, one of which is the frequency of eating, have a significant effect on gastritis recurrence. This is in line with Silvi (2017) which states that there is a significant effect on the diet with gastritis $(\mathrm{OR}=10,150)$ in the working area of the Bebesan Community Health Center, Aceh Regency.

Based on the results of the Chi-square test, the p-value is 0.001 because the p-value is $<(0.05)$ so that Ho is rejected. The value of the odds ratio $(\mathrm{OR})=5.670(\mathrm{OR}>1)$ with $95 \% \mathrm{CI}=2.144-14.997$ shows that respondents who have irregular eating breaks have a 5.6 times greater risk of suffering from gastritis than respondents with regular meal breaks. So it can be said that the delay in eating is one of the risk factors for gastritis. According to Baliwati (2014), naturally, the stomach will continue to produce stomach acid in small amounts every time, after 4-6 hours after eating, usually, the glucose level in the blood has been absorbed and used up so that the body will feel hungry and at that time the amount of stomach acid is stimulated. . If someone is late eating up to 2-3 hours. Eating more and more stomach acid is produced so that it can irritate the gastric mucosa and cause pain around the epigastrium (Suparyanto, 2012). These results are also supported by research by Dwigint (2015). Naturally, the stomach will continue to produce stomach acid in small amounts every time, after 4-6 hours after eating, usually, a lot of glucose levels in the blood have been absorbed and used so that the body will feel hungry and at the time. it's the amount of gastric acid stimulated. Eating on time refers to the concept of three meals a day, namely breakfast, lunch, and dinner. 
The bivariate test results showed a p-value of 0.022 because the p-value $<(0.05)$ so that Ho was rejected. The odds ratio $(\mathrm{OR})=2,923(\mathrm{OR}>1)$ with $95 \% \mathrm{CI}=1,245-6,865$ indicates that respondents who have a habit of drinking tea $\geq 4$ cups/day have a 2.9 times greater risk of suffering from gastritis than respondents who have a habit of drinking tea $<4$ cups/day. So it can be said that the consumption of drinking tea is one of the risk factors for gastritis. Based on the results of the study, the frequency of drinking and types of drinks has a close association with the incidence of gastritis. Drinking coffee and tea that contain caffeine is one type of drink that is at risk. According to Shinya (2007) in Firman (2009), tea contains tannins which are easily peroxidized to tannic acid. Tannic acid harms the gastric mucosa causing gastric problems such as peptic ulcers. Drinking tea on an empty stomach can cause excessive pressure on the stomach (Firman, 2009).

The results showed that there was a relationship between consuming spicy food and the incidence of gastritis in the work area of the Pesanggrahan Public Health Center. The results of this study are supported by research which states that the risky foods in question are foods that can trigger and are proven to be associated with gastritis, namely spicy foods, sour foods, and high salty foods (Yunita, 2010). Consuming spicy food in excess will stimulate the digestive system, especially the stomach and intestines to contract. This will cause heartburn and heartburn accompanied by nausea and vomiting. These symptoms make the patient decrease his appetite if the habit of consuming spicy food more than once a week for at least 6 months is allowed to continue and can cause irritation of the stomach which is called gastritis (Brunner, 2002). According to research conducted by Yunita (2010), it is said that the frequency of eating spicy food is significantly related to the incidence of gastritis with a p-value of 0.034 and $\mathrm{OR}=9.416$. The more often you eat spicy foods, the more you are at risk of developing gastritis.

The results showed that there was a relationship between consuming tamarind and the incidence of gastritis in the working area of the Pesanggrahan Community Health Center. The conclusion is based on the results of the Chi-square test, namely the p-value of 0.001 because the $\mathrm{p}$ value $<(0.05)$ so Ho is rejected. The value of the odds ratio $(\mathrm{OR})=1.196(\mathrm{OR}>1)$ with $95 \% \mathrm{CI}=$ 1.801-2.478 shows that respondents who have the habit of consuming acidic foods have a 1.1 times greater risk of suffering from gastritis than respondents who do not have the habit of consuming sour foods. So it can be said that the consumption of acidic foods is one of the risk factors for gastritis. According to research conducted by Ratna Yunita (2010), there was a significant relationship between the consumption of eating spicy food and the consumption of eating acidic foods on the incidence of gastritis. The same thing was stated by $\mathrm{Su}$ (2008) who said that reducing the consumption of vinegar can reduce the risk of being infected with the H.pylori bacteria that causes gastritis. In the book by 
Sylvia Anderson Price, Pathophysiology, it is said that foods containing spices such as pepper, foods containing vinegar, and mustard can also be a cause of acute gastritis (1992).

The results showed that there was a relationship between consuming instant noodles and the incidence of gastritis in the working area of the Pesanggrahan Community Health Center. The conclusion is based on the results of the Chi-square test, namely the p-value of 0.003 because the pvalue $<(0.05)$ so Ho is rejected. The odds ratio $(\mathrm{OR})=10,444(\mathrm{OR}>1)$ with $95 \% \mathrm{CI}=2,855-38,211$ shows that respondents who have the habit of consuming instant noodles have a 10.44 times greater risk of suffering from gastritis than respondents who do not have the habit consuming instant noodles. So it can be said that the consumption of instant noodles is one of the risk factors for gastritis. Instant noodles contain vets in crystals which can irritate the gastric mucosal lining. This is what causes gastric disorders. However, the consumption of instant noodles must be consumed very often so that there is no interference with the gastric mucosal layer.

\section{CONCLUSIONS AND SUGGESTIONS}

Based on the results of research on the Analysis of Factors Associated with Gastritis Incidence in the Work Area of the Pesanggrahan Health Center in Adolescents in 2018, it can be concluded that there is a significant relationship between age, gender, knowledge where the p-value $<0.05$ and frequency of eating (spicy), tamarind, instant noodles), intermittent meals with gastritis events. Encouraging to improve health programs such as preparing promotion programs or health services that are more appropriate and targeted to overcome the incidence of gastritis, conducting counseling to public or private schools with the target of teenagers who will be able to provide information about gastritis.

\section{REFERENCES}

Baliwati.F.Y,dkk.2004.Pengantar Pangan dan Gizi.Jakarta: Penebar Swadaya.

Cahyono,S.2008.Gaya hidup dan Penyakit Modern.Yogyakarta: Kanisius

Depok Periode $01 \quad$ Januari-31 Desember 2009.Diambil dari http://www.library.upnvj.ac.id/pdf/4s1kedokteran/207311066/ABSTRAK.pdf

Firman.2009.Hubungan Antara Usia, Jenis Kelamin, dan Lama Penggunaan OAINS Pada Pasien Osteoarthritis Terhadap Kejadian Dyspepsia di RS.Bhakti Yudha

Gustin,Rahmi K.2011.Faktor-faktor yang berhubungan dengan kejadian Gastritis pada Pasien Berobat Jalan di Puskesmas Gulai Bancah Kota Bukittinggi Tahun 2011.Bukittinggi.

Kemenkes RI.2013.Pedoman Gizi Rumah Sakit.Jakarta : Kementrian Kesehatan RI

Rahmawati.Nia.2010.Hubungan antara Karakteristik Responden,Stres Psikoogis,perilaku makan dan minum dengan kekambuhan gastritis di puskesmas kecamatan lamongan tahun 2010. 
Rizema,P.2013.Gizi dan Diet.D-Medical,Yogyakarta

Selviana B.Y, 2015. Effect of Coffe andSstress with TheIincidence of Gastritis.Jurnal Fakultas Kedokteran Universitas Lampung VOL 4(2) Januari 2015.

Silvi Imayani et all.2017.Gastritis dan Faktor -faktor yang Berpengaruh di Puskesmas Bebesan Kabupaten Aceh Tengah.

Su et al.2008.Risk Factors for Heliobacter pylori infection in Patients with Chronic Gastritis. World

Chinese Journal of Digestology Volume 16, Issue 33, November 2008, Pages 3810-3813.

Sulastri.2012.Gambaran pola makan penderita gastritis di wilayah kerja puskesmas Kampar kiri hulu kecamatan Kampar kiri hulu kabupaten Kampar riau.Skripsi.Sumatera: Fakultas Kesehatan Masyarakat USU

Suparyanto.2012.Etiologi dan Penanganan Gastritis.Diambil dari http://drsparyanto.blogspot.com/2018/02/etiologi-dan-penanganan-gastritis.html. Diakses tanggal 02 februari 2018

World Health Organization.2011.Global Status Report On Noncommunicable Disease 2010.Geneva Yunita,Ratna.2010.Hubungan antara Karakteristik Responden,Kebiasaan Makan dan Minum,serta Pemakaian NSAID dengan Terjadinya Gastritis pada Mahasiswa Kedokteran.Diambil dari http://adln.fkm.unair.ac.id/gdl.php?mod=browse \&op=read\&id=adlnfkm-adln-ratnayunit1493.Diakses pada tanggal 14 Januari 2018 